Earth Syst. Sci. Data, 2, 1-15, 2010

www.earth-syst-sci-data.net/2/1/2010/

(c) Author(s) 2010. This work is distributed under

the Creative Commons Attribution 3.0 License.

\title{
Atlantic CFC data in CARINA
}

\author{
R. Steinfeldt ${ }^{1}$, T. Tanhua ${ }^{2}$, J. L. Bullister ${ }^{3}$, R. M. Key ${ }^{4}$, M. Rhein ${ }^{1}$, and J. Köhler ${ }^{1}$ \\ ${ }^{1}$ Institut für Umweltphysik, Univerität Bremen, Bremen, Germany \\ ${ }^{2}$ Leibniz-Institut für Meereswissenschaften, Marine Biogeochemie, Kiel, Germany \\ ${ }^{3}$ NOAA-Pacific Marine Environmental Laboratory, Seattle, WA 98115, USA \\ ${ }^{4}$ Atmospheric and Oceanic Sciences Program, Princeton University, Princeton, NJ 08544, USA
}

Received: 24 June 2009 - Published in Earth Syst. Sci. Data Discuss.: 9 July 2009

Revised: 16 November 2009 - Accepted: 17 November 2009 - Published: 11 January 2010

\begin{abstract}
Water column data of carbon and carbon-relevant parameters have been collected and merged into a new database called CARINA (CARbon IN the Atlantic). In order to provide a consistent data set, all data have been examined for systematic biases and adjusted if necessary (secondary quality control (QC)). The CARINA data set is divided into three regions: the Arctic/Nordic Seas, the Atlantic region and the Southern Ocean. Here we present the CFC data for the Atlantic region, including the chlorofluorocarbons CFC-11, CFC-12 and CFC-113 as well as carbon tetrachloride $\left(\mathrm{CCl}_{4}\right)$. The methods applied for the secondary quality control, a crossover analyses, the investigation of CFC ratios in the ocean and the CFC surface saturation are presented. Based on the results, the CFC data of some cruises are adjusted by a certain factor or given a "poor" quality flag.
\end{abstract}

\section{Data coverage and parameter measured}

Repository-Reference: doi:10.3334/CDIAC/otg.ndp091 (Tanhua et al., 2008b)

Available at: http://cdiac.ornl.gov/oceans/CARINA/Carina_inv.html

Coverage: $60^{\circ} \mathrm{S}-75^{\circ} \mathrm{N} ; 80^{\circ} \mathrm{W}-34^{\circ} \mathrm{E}$

Location Name: Atlantic Ocean

Date/Time Start: 1991-03

Date/Time End: 2005-02

\begin{tabular}{|c|c|c|c|c|}
\hline $\begin{array}{l}\text { Data Product } \\
\text { Parameter Name }\end{array}$ & $\begin{array}{l}\text { Data Product } \\
\text { Flag Name }\end{array}$ & $\begin{array}{l}\text { Exchange File } \\
\text { Parameter Name }\end{array}$ & $\begin{array}{l}\text { Exchange File } \\
\text { Flag Name }\end{array}$ & Units \\
\hline station & & STANBR & & \\
\hline latitude & & LATITUDE & & decimal degrees \\
\hline $\begin{array}{l}\text { longitude } \\
\text { depth }\end{array}$ & & LONGITUDE & & $\begin{array}{l}\text { decimal degrees } \\
\text { meters }\end{array}$ \\
\hline temperature & & CTDTMP & & ${ }^{\circ} \mathrm{C}$ \\
\hline salinity & sf & SALNTY & SALNTY_FLAG_W & \\
\hline pressure & & CTDPRS & & decibars \\
\hline cfc11 & $\operatorname{cfc} 11 \mathrm{f}$ & & & picomole $\mathrm{kg}^{-1}$ \\
\hline cfc12 & $\mathrm{cfc} 12 \mathrm{f}$ & & & picomole $\mathrm{kg}^{-1}$ \\
\hline cfc113 & $\operatorname{cfc} 113 f$ & & & picomole $\mathrm{kg}^{-1}$ \\
\hline $\mathrm{CCl}_{4}$ & $\mathrm{CCl}_{4} \mathrm{f}$ & & & picomole $\mathrm{kg}^{-1}$ \\
\hline pf11 & & & & ppt \\
\hline pf12 & & & & ppt \\
\hline pf113 & & & & ppt \\
\hline $\mathrm{pCCl}_{4}$ & & & & ppt \\
\hline
\end{tabular}

For a complete list of parameters for the CARINA data base, see Key et al. (2009). Note the different names for the parameters in the Exchange files (the individual cruise files) and the merged data product. The quality flags according to the WOCE code are 2 (acceptable), 3 (questionable), 4 (bad or "poor" throughout this paper), 6 (mean of replicate), and 9 (not measured).

Correspondence to: R. Steinfeldt

(rsteinf@physik.uni-bremen.de)

Published by Copernicus Publications. 


\section{Introduction}

CARINA is a database of carbon relevant data from hydrographic cruises in the Arctic, Atlantic and Southern Oceans. The project was formed as an essentially informal, unfunded project in Kiel, Germany, in 1999, with the main goal to create a database of carbon relevant variables in the ocean to be used for accurate assessments of oceanic carbon inventories and uptake rates. Not only the collection of data, but also the quality control of the data has been a main focus of the project. During the project, both primary and secondary quality control (QC) of the data has been performed. A comprehensive description of the complete CARINA data base can be found in Key et al. (2009) as well as the other, more specialized, papers in this special issue. An overview of the Atlantic Ocean part of CARINA (CARINA-ATL) is given by Tanhua et al. (2009). The CARINA database consists of essentially two parts: The first part is the individual cruise files where all the measured data, and their quality flags, are stored. These files are in WHP exchange format where the first lines consist of the condensed metadata. There are essentially no calculated nor any interpolated values in the individual cruise files, and no adjustments have been applied to the values. In many cases there are more reported parameters in the individual cruise files than have been included in the secondary QC, such as ${ }^{14} \mathrm{C},{ }^{13} \mathrm{C}$ and $\mathrm{SF}_{6}$.

The second part of CARINA is the merged data files. These are files with all the CARINA data and include: Interpolated values for nutrients, oxygen and salinity if those data are missing and if interpolation can be made according to criteria described in Key et al. (2009); Calculated carbon parameters (e.g. if $\mathrm{TCO}_{2}$ and alkalinity was measured, $\mathrm{pH}$ can be calculated). Calculated and interpolated values have the quality flag " 0 ". All the tracer values in the merged data file have been adjusted according to the values in Table 2 .

In this paper we describe the data and provide an overview of the secondary quality control of the CFC data included in the CARINA-ATL data base. We refer to the four compounds CFC-11, CFC-12, CFC-113 and $\mathrm{CCl}_{4}$ as $\mathrm{CFCs}$, although strictly speaking $\mathrm{CCl}_{4}$ is not a CFC. CFCs are not directly carbon related data. They are, however, included into the CARINA data base, as they provide information on water mass ventilation and age and thus they are helpful in the estimation of anthropogenic carbon (e.g. Waugh et al., 2006). The secondary quality control has to take into consideration two aspects: The first is the transient nature of the CFCs, i.e. they have increased in the atmosphere during the last decades, and this increase will be reflected by the CFC-concentrations in the ocean interior. The second is the large range of CFC values in the deep water of the North Atlantic. In the convection regions such as the Labrador Sea, the values almost reach the solubility equilibrium with the present atmospheric CFC concentrations, whereas in other areas (e.g. the tropics away from the Deep Western Boundary Current), the concentration often approaches the detection
Table 1. List of all CARINA-ATL CFC data. Crosses in brackets indicate that the CFC component has been measured, but all data are flagged 3 or 4, either directly by the PI or after the QC procedure. These data are not included in the CARINA data product (Key et al., 2009).

\begin{tabular}{|c|c|c|c|c|c|}
\hline Cruise \# & Expocode & CFC-11 & $\mathrm{CFC}-12$ & CFC-113 & $\mathrm{CCl}_{4}$ \\
\hline \multicolumn{6}{|c|}{ Atlantic Ocean } \\
\hline 05 & 06BE20001128 & $\mathrm{x}$ & $\mathrm{x}$ & - & - \\
\hline 11 & 06МТ19940219 & $\mathrm{x}$ & $\mathrm{x}$ & - & - \\
\hline 12 & 06МТ19941012 & $\mathrm{x}$ & $\mathrm{x}$ & $\mathrm{x}$ & $\mathrm{x}$ \\
\hline 13 & 06МТ19941115 & $\mathrm{X}$ & $\mathrm{x}$ & - & - \\
\hline 17 & 06MT19970515 & $\mathrm{x}$ & $\mathrm{x}$ & - & - \\
\hline 18 & 06МТ19970707 & $\mathrm{x}$ & $(\mathrm{x})$ & - & - \\
\hline 19 & 06МТ19970815 & $\mathrm{x}$ & (x) & - & - \\
\hline 20 & 06МТ19990610 & $\mathrm{x}$ & $\mathrm{x}$ & - & - \\
\hline 21 & 06MT19990711 & $\mathrm{x}$ & $\mathrm{x}$ & - & - \\
\hline 22 & 06МТ19990813 & $\mathrm{x}$ & $\mathrm{x}$ & - & - \\
\hline 23 & 06МT20010507 & $\mathrm{x}$ & $\mathrm{x}$ & - & - \\
\hline 24 & 06МT20010620 & $\mathrm{x}$ & $\mathrm{x}$ & - & - \\
\hline 25 & 06МТ20010717 & $\mathrm{x}$ & $\mathrm{x}$ & - & - \\
\hline 26 & 06МT20011018 & $\mathrm{x}$ & $\mathrm{x}$ & $\mathrm{x}$ & - \\
\hline 27 & 06МТ20020607 & $\mathrm{x}$ & $\mathrm{x}$ & - & - \\
\hline 29 & 06МТ20030626 & $\mathrm{x}$ & $\mathrm{x}$ & - & - \\
\hline 30 & 06МT20030723 & $(\mathrm{x})$ & $\mathrm{x}$ & - & - \\
\hline 31 & 06МТ20030831 & $\mathrm{x}$ & $\mathrm{x}$ & - & - \\
\hline 32 & 06МT20040311 & $\mathrm{x}$ & $\mathrm{x}$ & - & $\mathrm{x}$ \\
\hline 37 & 18HU19920527 & $\mathrm{x}$ & $\mathrm{x}$ & - & $\mathrm{x}$ \\
\hline 39 & 18HU19930617 & $\mathrm{x}$ & $\mathrm{x}$ & $\mathrm{x}$ & $\mathrm{x}$ \\
\hline 40 & 18HU19931105 & $\mathrm{x}$ & $\mathrm{x}$ & (x) & $\mathrm{x}$ \\
\hline 41 & 18HU19940524 & $\mathrm{x}$ & $\mathrm{x}$ & (x) & $\mathrm{x}$ \\
\hline 42 & 18HU19941012 & (x) & (x) & $\mathrm{x}$ & $\mathrm{X}$ \\
\hline 43 & 18HU19950419 & $\mathrm{x}$ & (x) & $\mathrm{X}$ & (x) \\
\hline 44 & 18HU19970509 & $\mathrm{x}$ & $\mathrm{x}$ & (x) & (x) \\
\hline 68 & 316 N20030922 & $\mathrm{X}$ & $\mathrm{x}$ & $\mathrm{x}$ & $\mathrm{x}$ \\
\hline 69 & 316 N20031023 & $\mathrm{x}$ & $\mathrm{x}$ & $\mathrm{x}$ & $\mathrm{x}$ \\
\hline 71 & 32EV19910328 & $\mathrm{x}$ & $\mathrm{x}$ & $\mathrm{x}$ & - \\
\hline 84 & 33LK19960415 & $\mathrm{x}$ & $\mathrm{x}$ & - & - \\
\hline 85 & 33RO19980123 & $\mathrm{x}$ & $\mathrm{x}$ & $\mathrm{x}$ & $\mathrm{x}$ \\
\hline 86 & 33RO20030604 & $\mathrm{x}$ & $\mathrm{x}$ & $\mathrm{x}$ & - \\
\hline 87 & 33RO20050111 & $\mathrm{x}$ & $\mathrm{x}$ & $\mathrm{x}$ & $\mathrm{x}$ \\
\hline 95 & 35LU19950909 & $\mathrm{x}$ & $\mathrm{x}$ & - & - \\
\hline 106 & 35TH19990712 & $\mathrm{x}$ & - & - & - \\
\hline 113 & 49NZ20031106 & $\mathrm{x}$ & $\mathrm{x}$ & (x) & - \\
\hline 171 & 74DI19970807 & $\mathrm{x}$ & $\mathrm{x}$ & - & - \\
\hline 172 & 74DI19980423 & $\mathrm{x}$ & $\mathrm{x}$ & - & - \\
\hline 173 & 74DI20040404 & $\mathrm{x}$ & $\mathrm{x}$ & $\mathrm{x}$ & $\mathrm{x}$ \\
\hline \multicolumn{6}{|c|}{ Atlantic \& Arctic Ocean } \\
\hline 91 & 34AR19970805 & $\mathrm{x}$ & $\mathrm{x}$ & $\mathrm{x}$ & $\mathrm{x}$ \\
\hline 125 & 58AA20010527 & $\mathrm{x}$ & $\mathrm{x}$ & - & - \\
\hline 135 & 58JH19970723 & (x) & (x) & (x) & (x) \\
\hline \multicolumn{6}{|c|}{ Arctic Ocean included into X-over analyses } \\
\hline 77 & 58GS20030922 & $\mathrm{x}$ & $\mathrm{X}$ & - & - \\
\hline \multicolumn{6}{|c|}{ Cruises from GLODAP included into $\mathrm{x}$-over analyses } \\
\hline & 29HE19920714 & $\mathrm{X}$ & $\mathrm{x}$ & - & - \\
\hline & 316N19970717 & $\mathrm{x}$ & $\mathrm{x}$ & - & - \\
\hline & 316N19970815 & $\mathrm{x}$ & $\mathrm{x}$ & $\mathrm{x}$ & - \\
\hline & 317519930704 & $\mathrm{x}$ & $\mathrm{x}$ & - & - \\
\hline & 323019940104 & $\mathrm{x}$ & $\mathrm{x}$ & - & - \\
\hline
\end{tabular}


Table 2. List of cruises with adjustments for CFC data and assignments of a "poor" quality flag. A "poor" quality flag has been assigned in the case of large data spread, which cannot be corrected by a simple adjustment factor.

\begin{tabular}{cccccc}
\hline Cruise \# & EXPOCODE & CFC-11 & CFC-12 & CFC-113 & CCl $_{4}$ \\
\hline 37 & 18 HU19920527 & good & 1.05 & - & good \\
40 & 18 HU19931105 & good & good & poor & good \\
41 & 18 HU19940524 & 1.05 & good & poor & good \\
42 & 18 HU19941012 & poor & poor & good & good \\
43 & 18 HU19950419 & good & poor & good & poor \\
44 & 18HU19970509 & good & good & poor & poor \\
84 & 33LK19960415 & good & 1.1 & - & - \\
91 & 34AR19970805 & 0.95 & good & good & good \\
95 & 35LU19950909 & 0.9 & good & - & - \\
106 & 35TH19990712 & 0.85 & - & - & - \\
113 & 49NZ20031106 & 0.95 & good & - & - \\
135 & 58JH19940723 & poor & poor & poor & poor \\
\hline
\end{tabular}

limit (e.g. Smethie et al., 2000). These characteristics of CFC data make a straightforward application of the adjustment procedure of Johnson et al. (2001) impossible.

\section{Data provenance}

The CARINA database includes 42 cruises with CFC-11, 41 cruises with CFC-12, 18 cruises with CFC-113, and 16 cruises with $\mathrm{CCl}_{4}$ for the Atlantic Ocean region, see Fig. 1 for a map of positions of these measurements and Fig. 2 for the CFC-11 data of each cruise. Overall, there are more than 54.000 samples where at least one CFC component was measured in CARINA-ATL. Regionally, most data are from the subpolar North Atlantic, whereas towards the South Atlantic large data gaps remain.

CFCs are measured by purge and trap gas chromatography. The analytical systems described in Bullister and Weiss (1988) and in Bulsiewicz et al. (1998) have been applied for the large quantity of CFC measurements used for the CARINA data set. The data precision varies between the different CFC components and analytical labs between $1 \%$ and 3\% for CFC-11 and CFC-12 (Bulsiewicz et al., 1998; Rhein et al., 2002; Azetsu-Scott et al., 2005), 2\% and 4\% for $\mathrm{CCl}_{4}$ (Bulsiewicz et al., 1998; Azetsu-Scott et al., 2005), and about $2 \%$ for CFC-113 (Bulsiwicz et al., 1998). Together with the accuracies of the gas standards of $1 \%$ to $3 \%$, the overall accuracy is $5 \%$ or better. (Detailed information on the accuracy for single cruises is given in the files on the CARINA cruise table, http://cdiac.ornl.gov/oceans/ CARINA/Carina_table.html).

The detection limit is normally less than $0.01 \mathrm{pmol} \mathrm{kg}^{-1}$ for all components. In some cases, a sampling blank has been subtracted from the data (e.g. Tanhua et al., 2008a), which is typically of the order of $0.01 \mathrm{pmol} \mathrm{kg}^{-1}$. This blank can only be easily detected, if CFC data from regions with very low

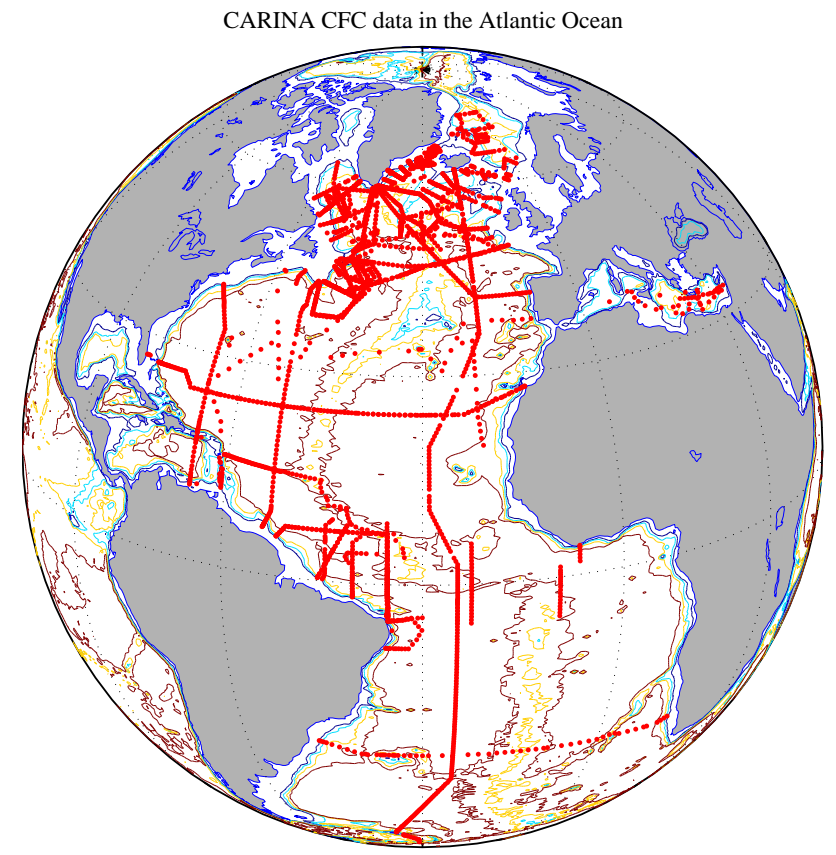

Figure 1. Map of the positions of all stations with at least one CFC measurement in the CARINA dataset for the Atlantic Ocean.

CFC concentrations are collected. Thus for cruises from the northwestern Atlantic, where CFC concentrations are high throughout the water column, blank corrections are typically not applied to the CFC data. The smallest possible reproducibility is typically about $0.005 \mathrm{pmol} \mathrm{kg}^{-1}$ (Bulsiewicz et al., 1998). For CFC concentrations below $0.1 \mathrm{pmol} \mathrm{kg}^{-1}$, the (relative) accuracy is thus larger than 5\%. Analyses of CFC11 data from different cruises for Labrador Sea Water in the North Atlantic in Rhein et al. (2002) revealed a CFC-11 difference between cruises of $4.5 \%$. Most of this discrepancy was ascribed to the uncertainty of the gas standard used for calibration. An error of the gas standard will lead to a multiplicative offset of the CFC values. We thus assume a multiplicative offset to be the dominating part and perform the second order quality control to determine this multiplicative offset. The small $\left(\sim 0.01 \mathrm{pmol} \mathrm{kg}^{-1}\right)$ additional offset due to a sampling blank is hard to determine. The crossovers would have to be restricted to depth ranges of very small CFC concentrations, and even then the offset might be of the same order as the temporal CFC increase between cruises.

In the cases where the CFC scale of the data have been provided by the PI, the data have been converted onto the SIO-98 scale (Prinn et al., 2000). This is indicated in the metadata of the single cruise files. The differences between the CFC scales are smaller than $1 \%$, so an unknown CFC-scale can be regarded as a minor contribution to the total error. 

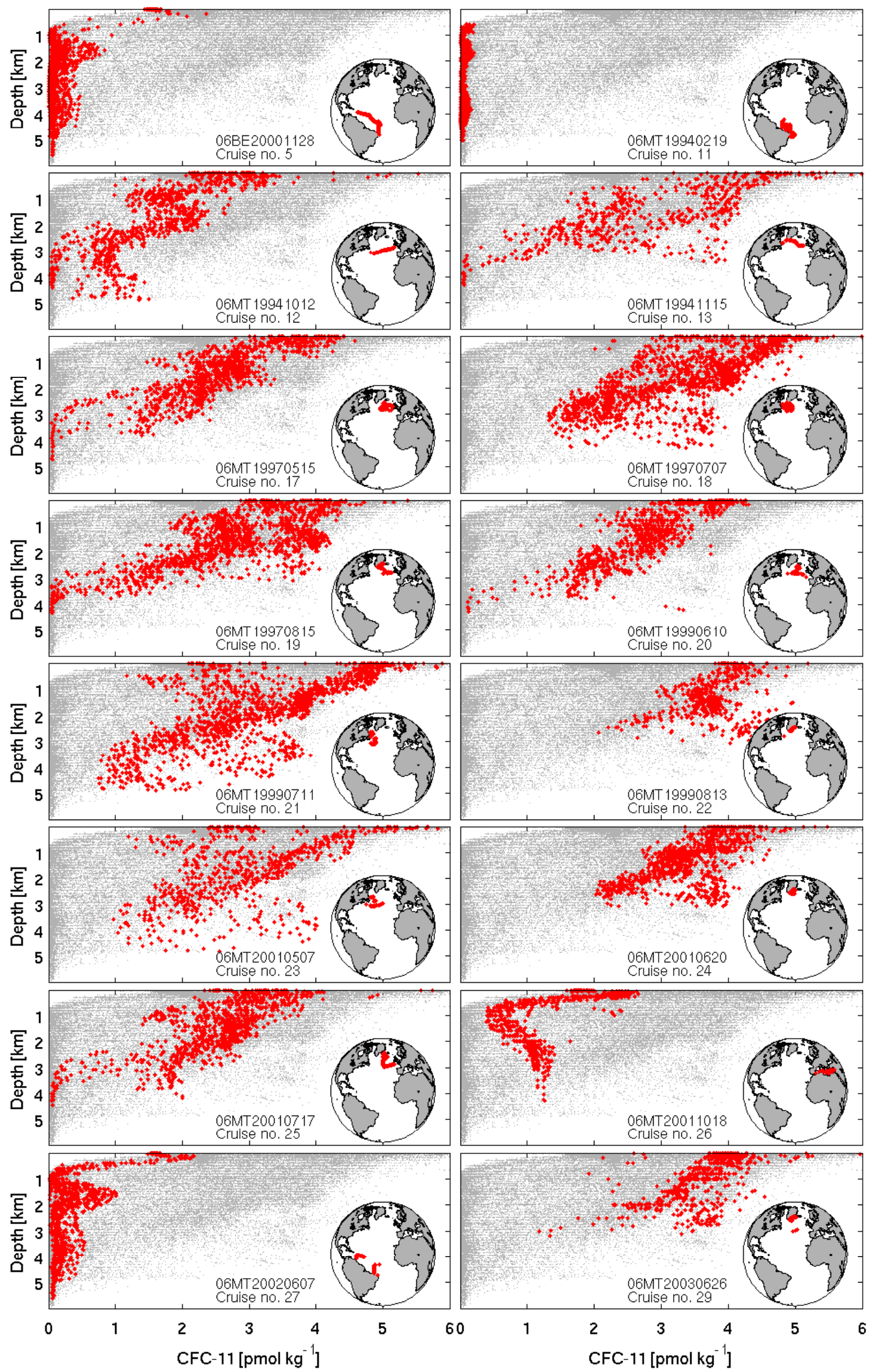

Figure 2. CFC-11 vs. depth for each cruise of the CARINA Atlantic data set. 

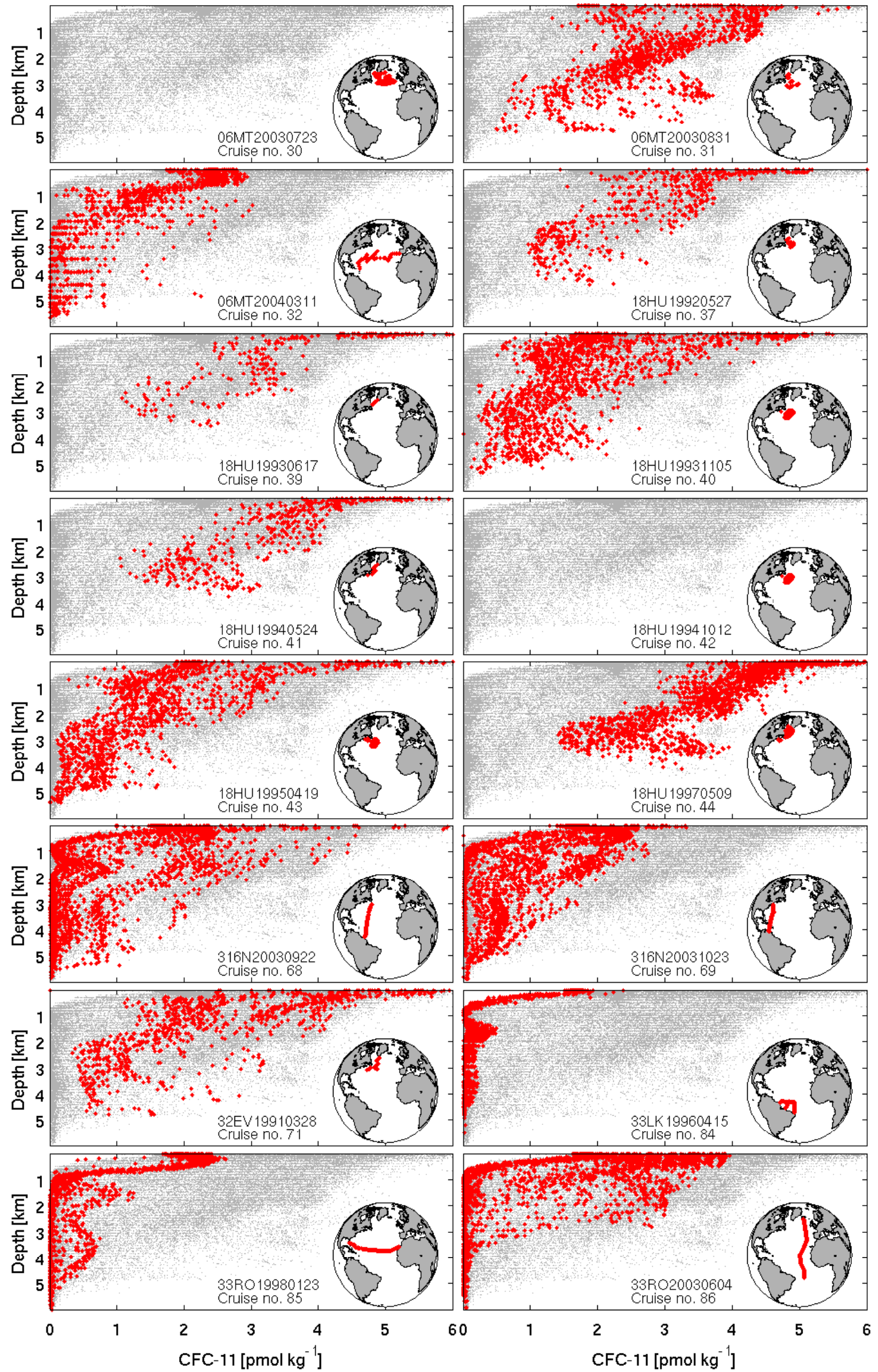

Figure 2. Continued. 

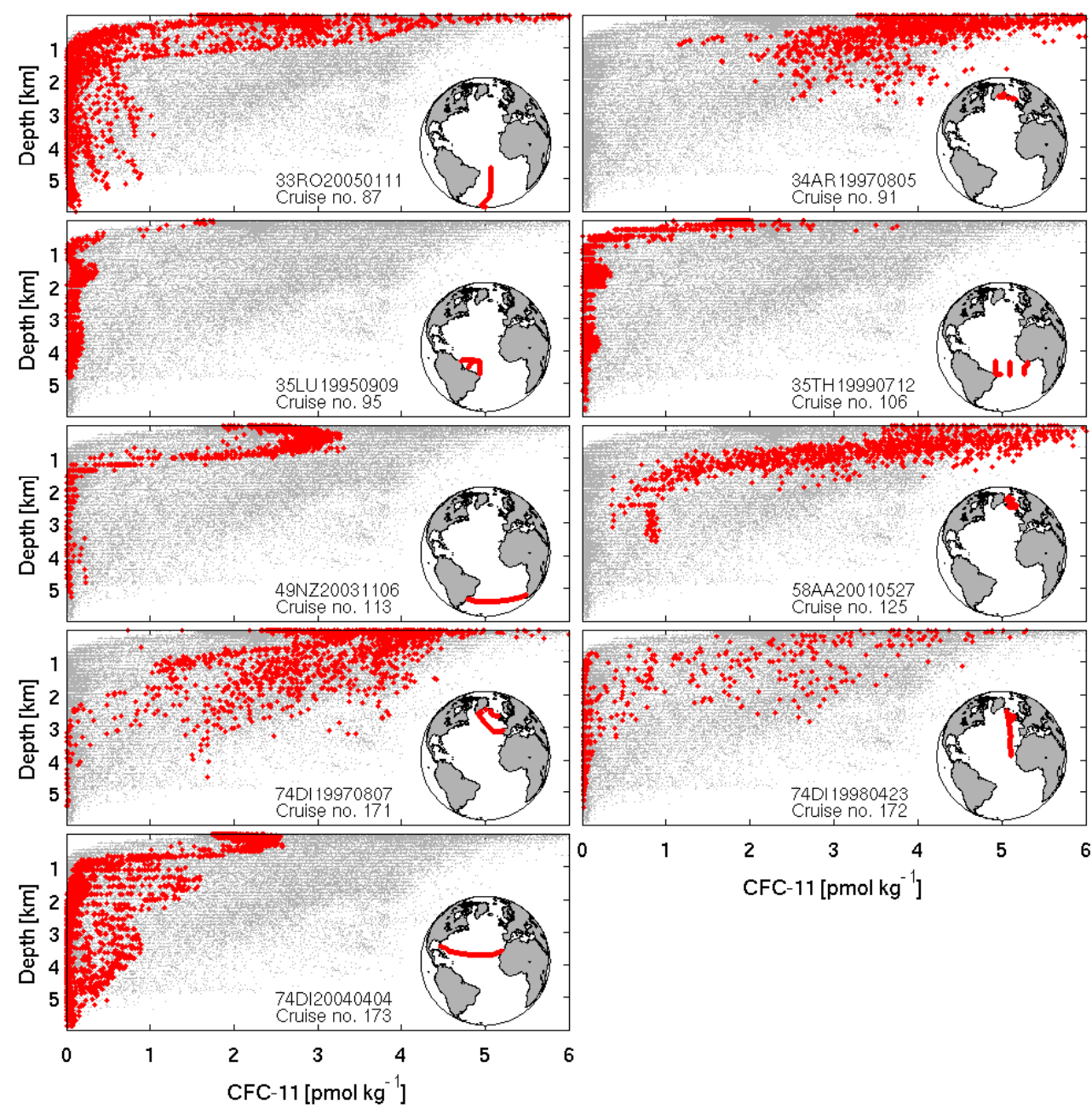

Figure 2. Continued.

\section{Computational analysis approach}

The quality control of the CARINA-ATL CFC data largely followed the procedures described in Tanhua et al. (2009), but with some important exceptions that are described below. As for most other parameters in CARINA, crossover analysis was a part of the secondary QC, but several other methodologies were used for the CFC data.

\subsection{Crossover analysis}

For the Atlantic part of the CARINA data set (CARINAATL), 243 crossovers for CFC-11, 226 for CFC-12, 46 for CFC-113 and 44 for $\mathrm{CCl}_{4}$ have been analyzed. These cruises not only encompass the CARINA Atlantic cruises, but also some cruises from the CARINA Arctic/Nordic Seas data set and some reference cruises are included, in order to guarantee consistency between the different regional CARINA data sets and earlier, non-CARINA data. The cruises included from the CARINA Arctic region as well as non-CARINA data used for the QC are indicated in Table 2. In most cases, only data below $1500 \mathrm{~m}$ depth have been used. The analyses have been carried out on $\sigma_{2}$ or $\sigma_{4}$ surfaces, depending on the maximum depths of the profiles, and multiplicative offsets between two cruises at a crossover location have been computed according to Johnson et al. (2001). The offset or crossover residual $f$ is the deviation of the ratios of the concentration of a CFC component from unity, i.e. $f=\mathrm{CFC}($ cruise 1$) / \mathrm{CFC}($ cruise 2$)-1$. Due to the time difference between compared profiles ( $>10 \mathrm{yr}$ in some cases) and the CFC-increase with time, some crossovers have ratios of $\mathrm{CFC}$ (cruise1)/CFC(cruise2) that are much larger or smaller than 1. This leads to a non-linearity, as the multiplicative offsets $f$ are dealt with in the same way as additive offsets by the routine from Johnson et al. (2001). If a cruise is too large by a factor of $1+f$, the routine would suggest a correction factor of $1-f$ instead of $(1+f)^{-1}$. The larger the offset $f$, the larger the error due to this non-linearity. Crossover results with $|f|>0.5$ are thus not taken into account for the secondary QC. 


\subsection{Results of the Least square method}

The results of the standard least square method (LSQ) from Johnson et al. (2001), as well as the mean of the crossovers for each cruise are shown in Fig. 4. The suggested corrections for the CFC data are of the order of $\pm 20 \%$, and in some cases they even reach a value of $\pm 50 \%$. A correction of the CFC data by $20 \%$ or more, however, seems in most cases not justified when considering the single crossover results.

The reason for the large corrections is probably due to the general temporal increase of CFCs in connection with the large temporal variability in the North Atlantic. This variability also influences all other, non-transient quantities, as salinity, oxygen, nutrients, etc. For these quantities, however, in the deep eastern North Atlantic and the tropical Atlantic cross over points remain, where the temporal variability is small. Even for crossovers with a large time difference between the two cruises in these regions, almost only measurement relevant biases remain. This, however, does not hold for CFCs. In old water, as can be found in the tropics and the deep north eastern Atlantic, the CFC values are so small, that the measurement error and a possible sampling blank become important. As can be seen from Fig. 3, for older water the expected CFC increase is largest, so that the time correction using a mean offset is not sufficient in these regions. This leads to crossover results for CFCs in very old water which are considerable different from unity, which causes the unrealistic high corrections resulting from the least square method.

It might be expected that the general temporal increase of atmospheric CFCs leads to the effect that early cruises have, in most cases, lower CFC concentration than the more recent cruises to which they are compared. For some cruises, this is supported both from the mean of the crossovers as well as from the inversion results (e.g. 06MT19940219 and 29HE19920714 in Fig. 4). Surprisingly, the earliest cruise, 18 HU19820228, has only slightly negative results both for CFC-11 and CFC-12, which indicates that the increasing $\mathrm{CFC}$ trend with time in the northern Atlantic is overlayed by large temporal variability.

\subsection{CFC partial pressure and saturation}

As the results of the least square methods result in unrealistically high correction factors for many cruises, additional methods have to be applied for the the CFC quality control. One of these is the consideration of the CFC saturation near the surface (for samples with a pressure of $p<20 \mathrm{dbar}$ ). In order to calculate the saturation, the oceanic CFC concentrations (in pmol/ $\mathrm{kg}$ ) have to be converted to an atmospheric mixing ratio (in ppt) via the solubility function. These so called pCFC data are included in the CARINA data product. The solubilities are computed according to Warner and Weiss (1985) for CFC-11 and CFC-12, Bu and Warner (1995) for CFC-113, and Bullister and Wisegarver (1998) for $\mathrm{CCl}_{4}$.

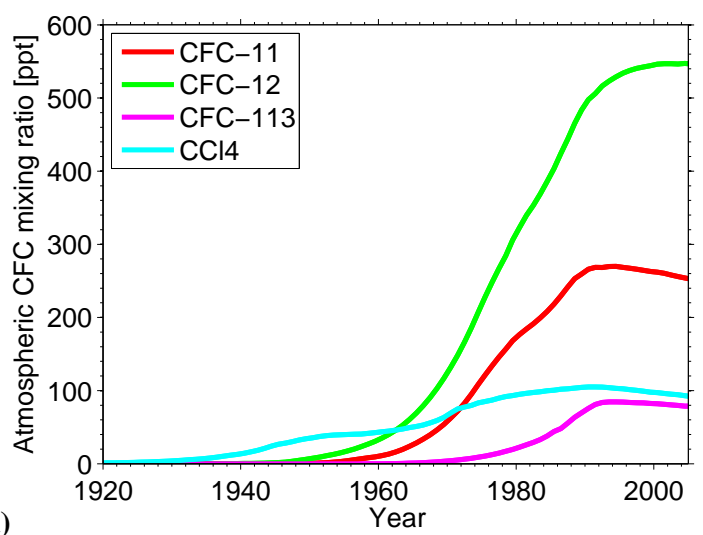

(a)

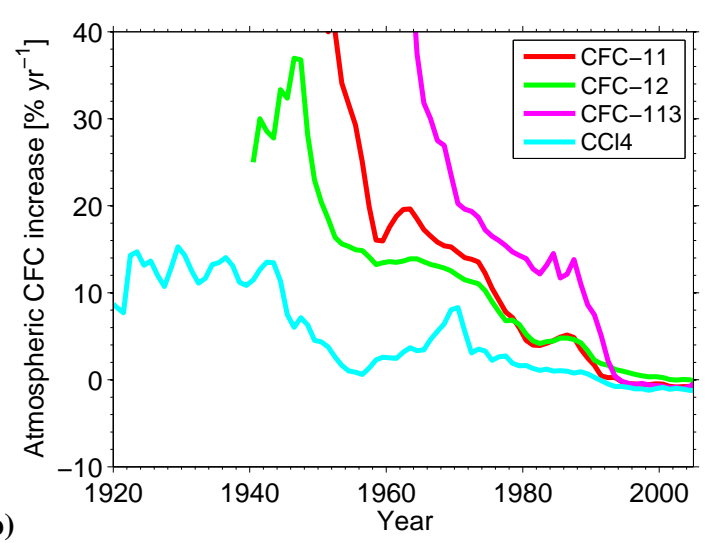

Figure 3. (a) Atmospheric CFC time histories, (b) Relative annual CFC increase rates. Atmospheric CFC data are from Walker et al. (2000).

The mean saturation of all surface samples of CFC-11 for each cruise is shown in Fig. 5. A deviation of the saturation from $100 \%$ and a larger error bar does not automatically imply a poor data quality, as the saturation is not necessarily around $100 \%$. During water mass formation, e.g., a considerable under-saturation may occur (Rhein et al., 2002). As the CFC exchange with the atmosphere is slower than for heat, strong surface cooling or warming may result in CFC underor over-saturation. After applying the adjustments, the mean surface saturation of CFC-11 is in the range of $90 \%-110 \%$, the only exception being the Hudson cruises form 1992 and 1993 with a saturation of around 80\% (Fig. 5). These cruises are from the western North Atlantic, especially the Labrador Sea, and the low CFC saturation may be caused by the intense deep convection in the Labrador Sea between 1987 and 1994 (Yashayaev, 2007), which leads to the intrusion of older water with low CFC-concentrations into the surface mixed layer. 


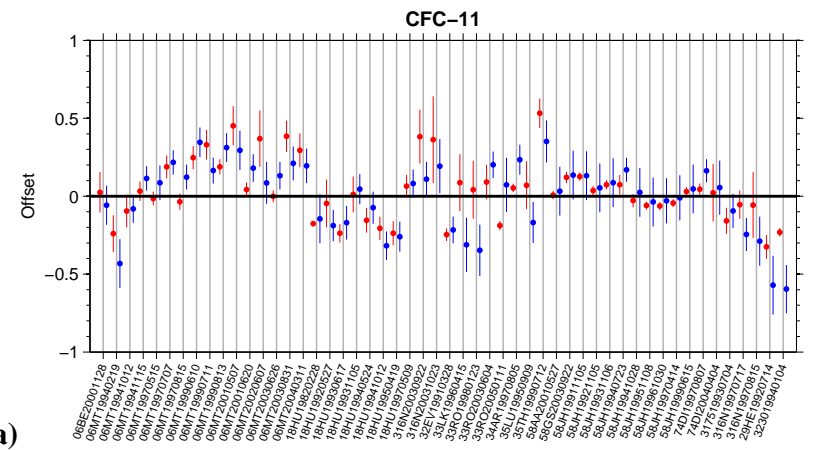

(a)

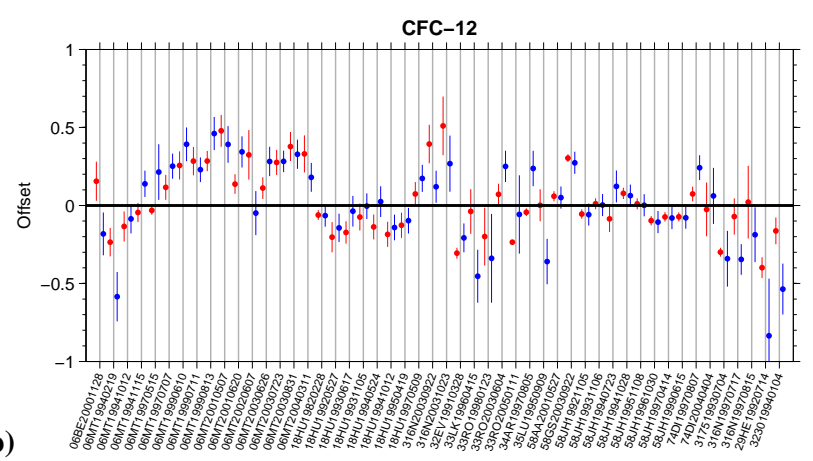

Figure 4. Mean value for all crossovers of each cruise (red) and offsets from the least square crossover analyses (blue) as suggested by the LSQ inversions for all CFC-components from the CARINAATL data set. Vertical lines denote the error range (standard deviation for the mean values and statistical uncertainty for the offsets). Some cruises of the Arctic/Nordic Seas region and non-CARINA data are included to get an overlap between the regions and provide consistency towards other data sets. (a) CFC-11, (b) CFC-12, (c) CFC-113, (d) $\mathrm{CCl}_{4}$.

For most CARINA cruises, more than one CFC component has been measured. The comparison of the saturations of the different CFCs also allow an estimation of the data quality. Typically, the saturations for CFC-11 and CFC-12 differ only by a few percent. This is illustrated in Fig. 6, where the saturations of $\mathrm{CFC}-12, \mathrm{CFC}-113$ and $\mathrm{CCl}_{4}$ are regressed towards the saturation of CFC-11. Compared with CFC-11, the saturation of CFC-12 is larger by only $1 \%$, whereas for $\mathrm{CCl}_{4}$ it is smaller by $5 \%$ and for CFC- 113 even by $19 \%$. The smaller surface saturation of $\mathrm{CFC}-113$ and $\mathrm{CCl}_{4}$ can be explained by their larger Schmidt numbers and thus smaller gas transfer velocities, which may lead to larger under-saturation. Additionally, these two CFC-components are not stable in warmer waters (e.g. Roether et al., 2001; Huhn et al., 2001). This oceanic sink of CFC-113 and $\mathrm{CCl}_{4}$ in the mixed layer may also decrease their surface saturation.

The mean residuals for each cruise of the regression between the CFC saturations (CFC-12, CFC-113 and $\mathrm{CCl}_{4}$ towards CFC-11 as described in Fig. 6) are shown in Fig. 7. Here, the deviations and error bars are indeed an indicator for the quality at least of the CFC-11 and CFC-12 data.
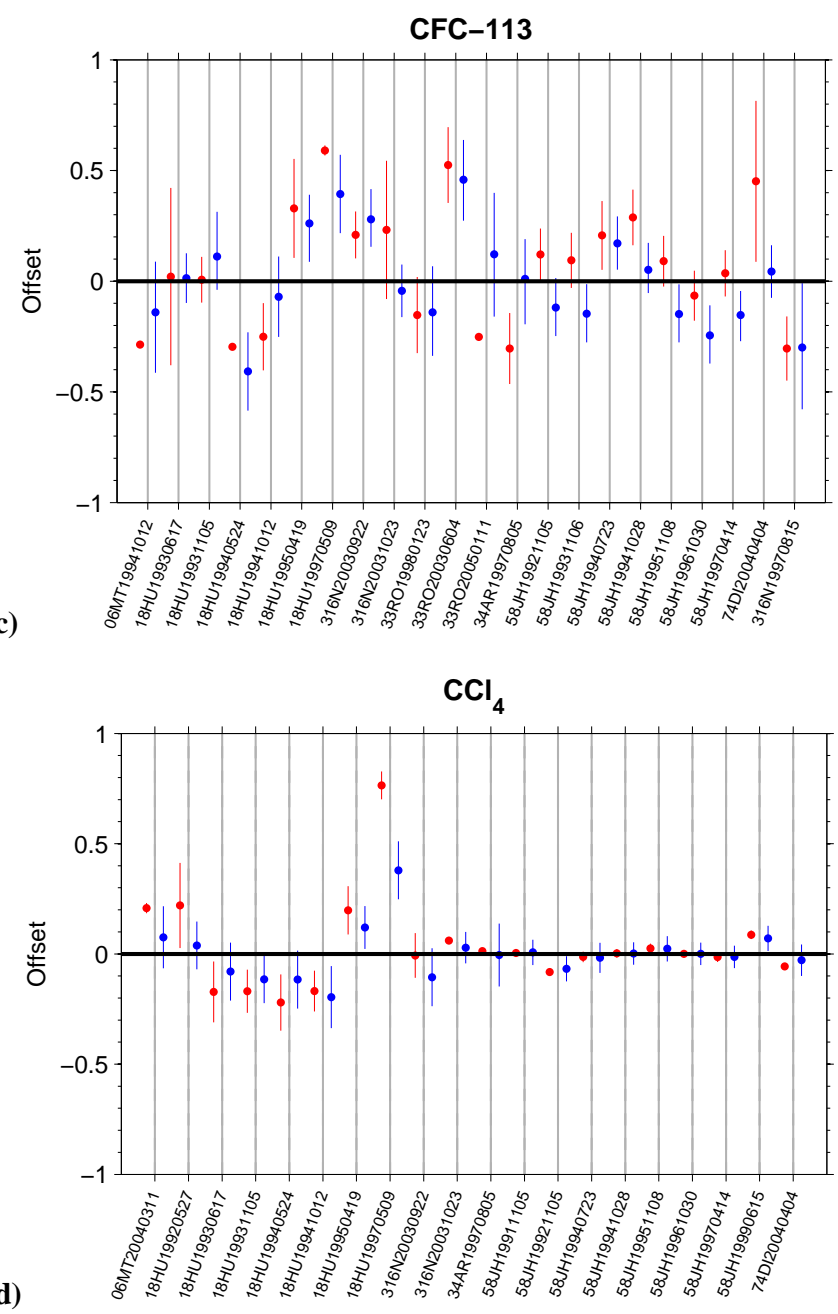

Figure 4. Continued.

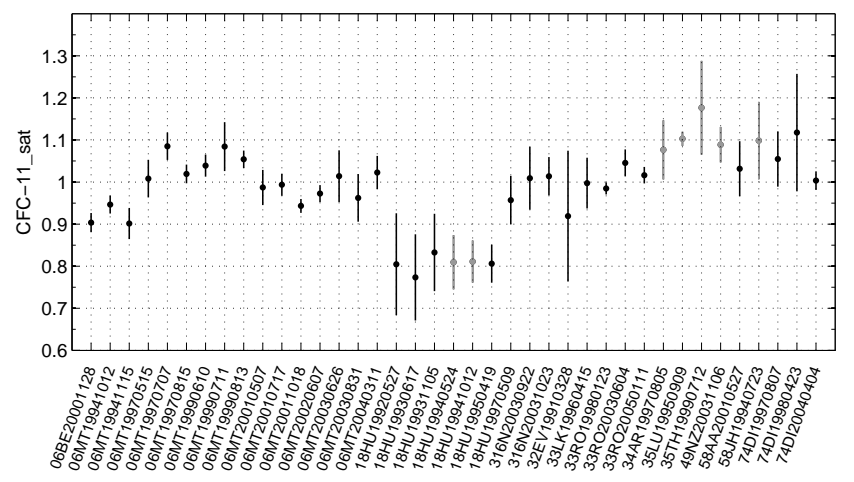

Figure 5. Mean surface saturation of CFC-11 for each cruise from the CARINA-ATL data set. Cruises were the CFC-11 data have been corrected or flagged as "poor" are highlighted in grey. 


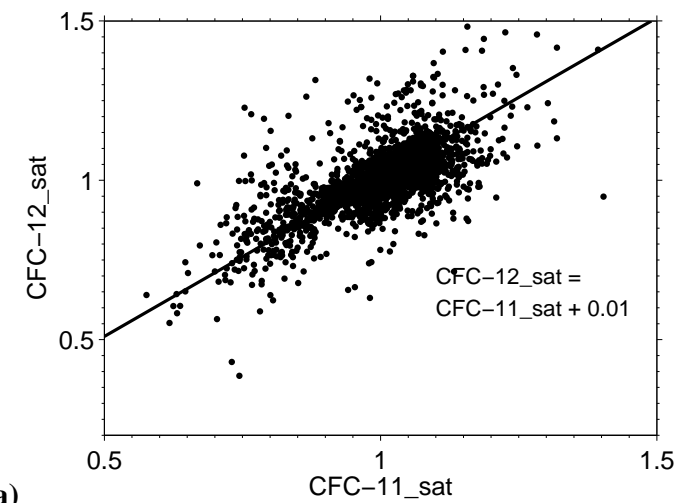

(a)

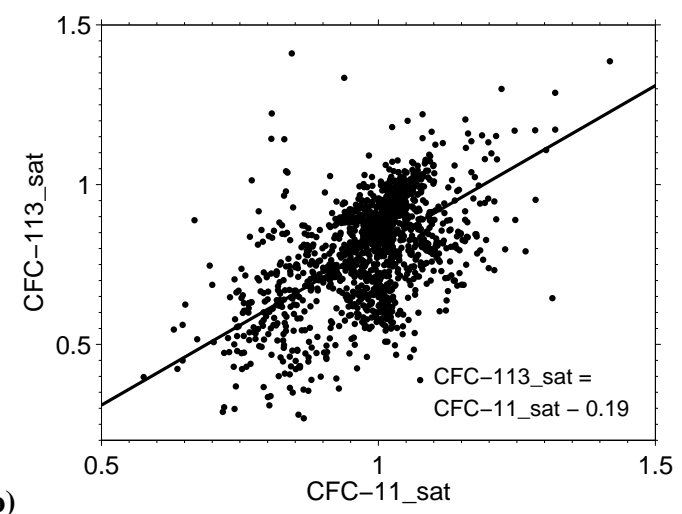

(b)

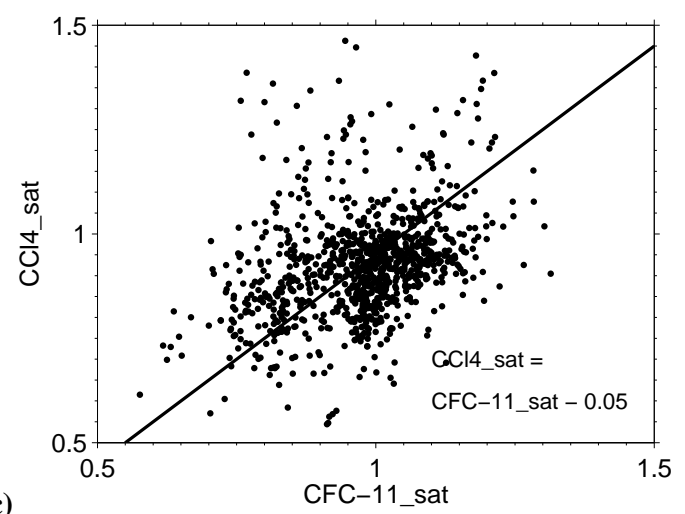

Figure 6. Correlation of surface saturation between: (a) CFC12/CFC-11, (b) CFC-113/CFC-11, and (c) $\mathrm{CCl}_{4} / \mathrm{CFC}-11$ for all cruises that have been included into the $2 \mathrm{nd} \mathrm{QC}$ for the Atlantic region.

For the data flagged as good, the deviation of the observed CFC-12 saturation from the simple linear regression towards the CFC-11 saturation is not larger than 5\% (after applying the adjustments given in Table 2), and the standard deviation of the residuals is also of the order of 5\% in most cases (Fig. 7). This implies that the CFC-11 and CFC-12 surface data are consistent within $5 \%$. As the relative measurement error resulting from the gas standard also applies to the CFC data from the ocean interior, possible offsets in the surface saturation can be transferred to all CFC data from the respec-
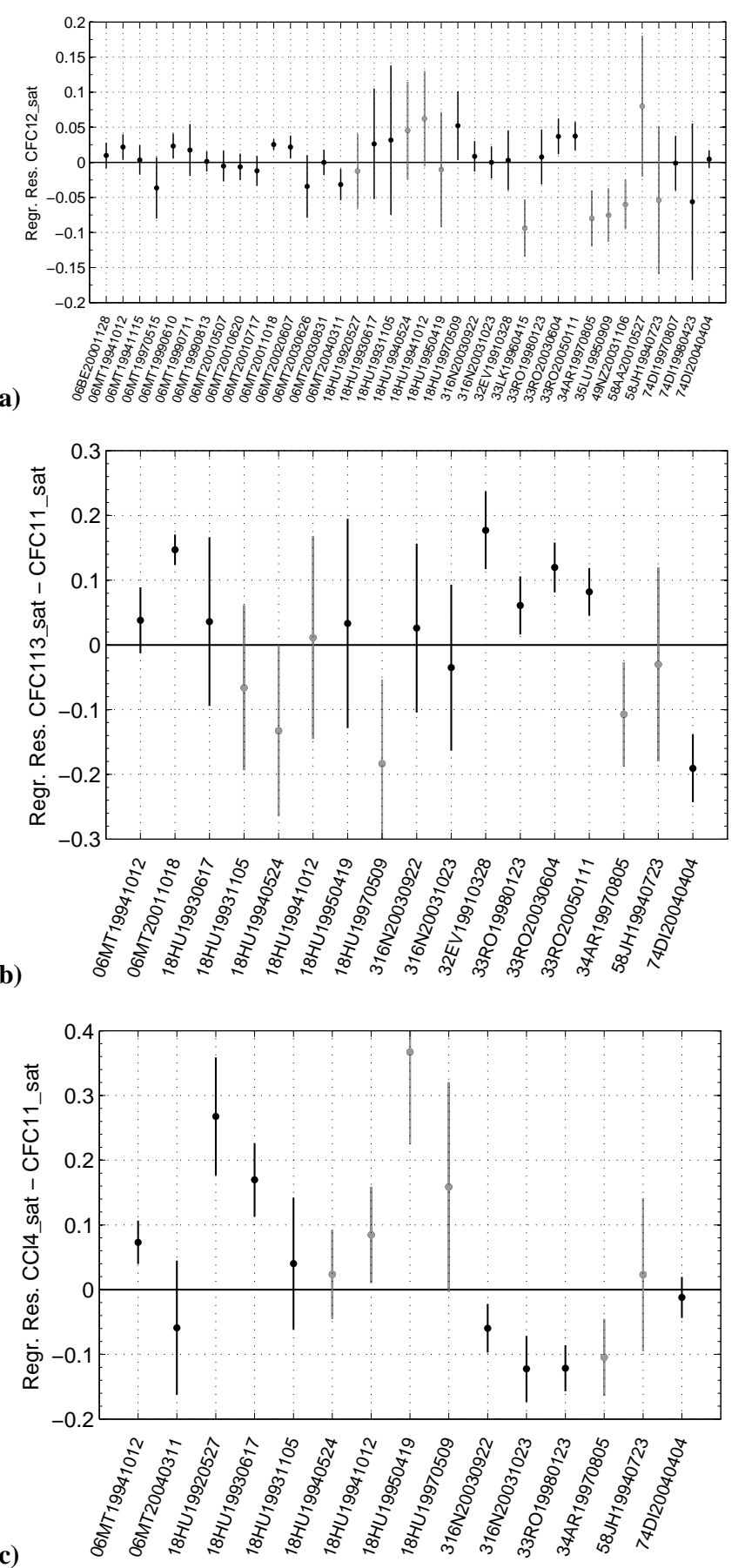

Figure 7. Mean regression residuals for each cruise included into the CARINA-ATL data product between the surface saturation of (a) CFC-12/CFC-11, (b) CFC-113/CFC-11, and (c) $\mathrm{CCl}_{4} / \mathrm{CFC}-11$. Cruises were the CFC-11 data and/or the regressed CFC component have been corrected or flagged as poor are highlighted in grey.

tive cruise. For CFC-113 and $\mathrm{CCl}_{4}$, the decomposition of these tracers in warm waters leads to larger deviations from the simple linear regression. 

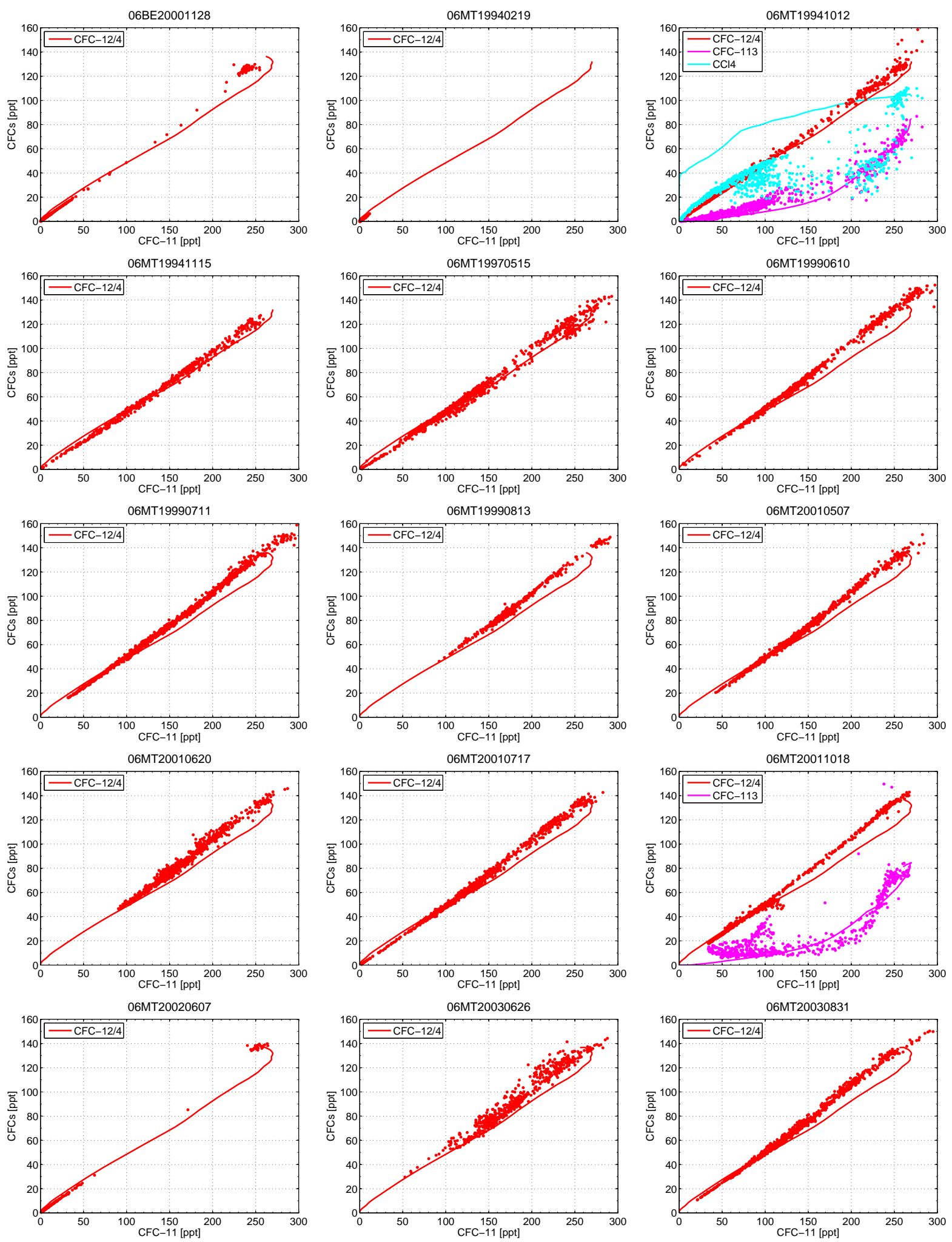

Figure 8. Property-property plot for CFC-12, CFC-113, and $\mathrm{CCl}_{4}$ against CFC-11 from the CARINA Atlantic data set. Oceanic CFC concentrations are converted to atmosphric mixing ratios, and the ratio of the atmospheric $\mathrm{CFC}$ concentrations are indicated by the solid lines. CFC-12 mixing ratios are devided by 4 to fit the scale. 

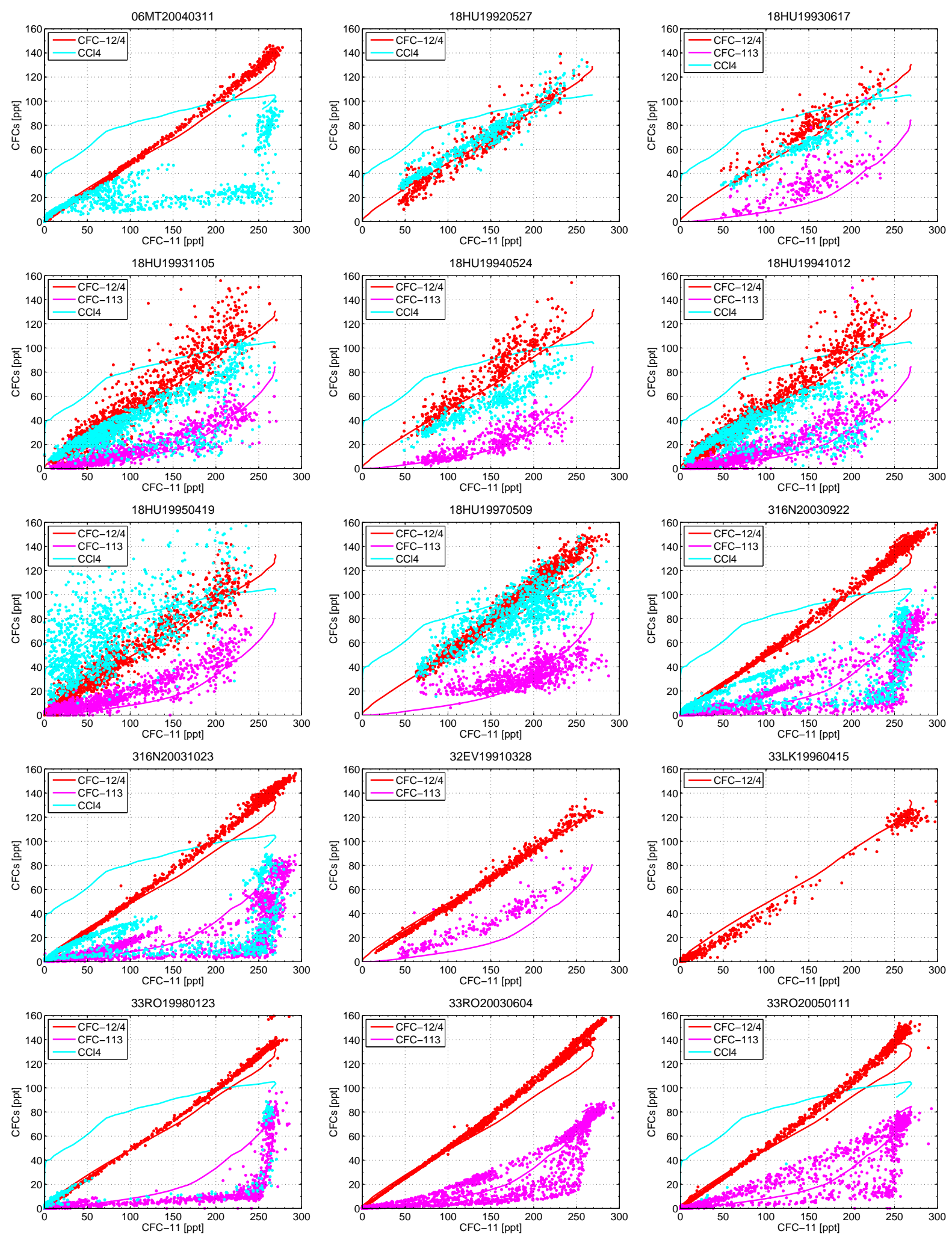

Figure 8. Continued. 

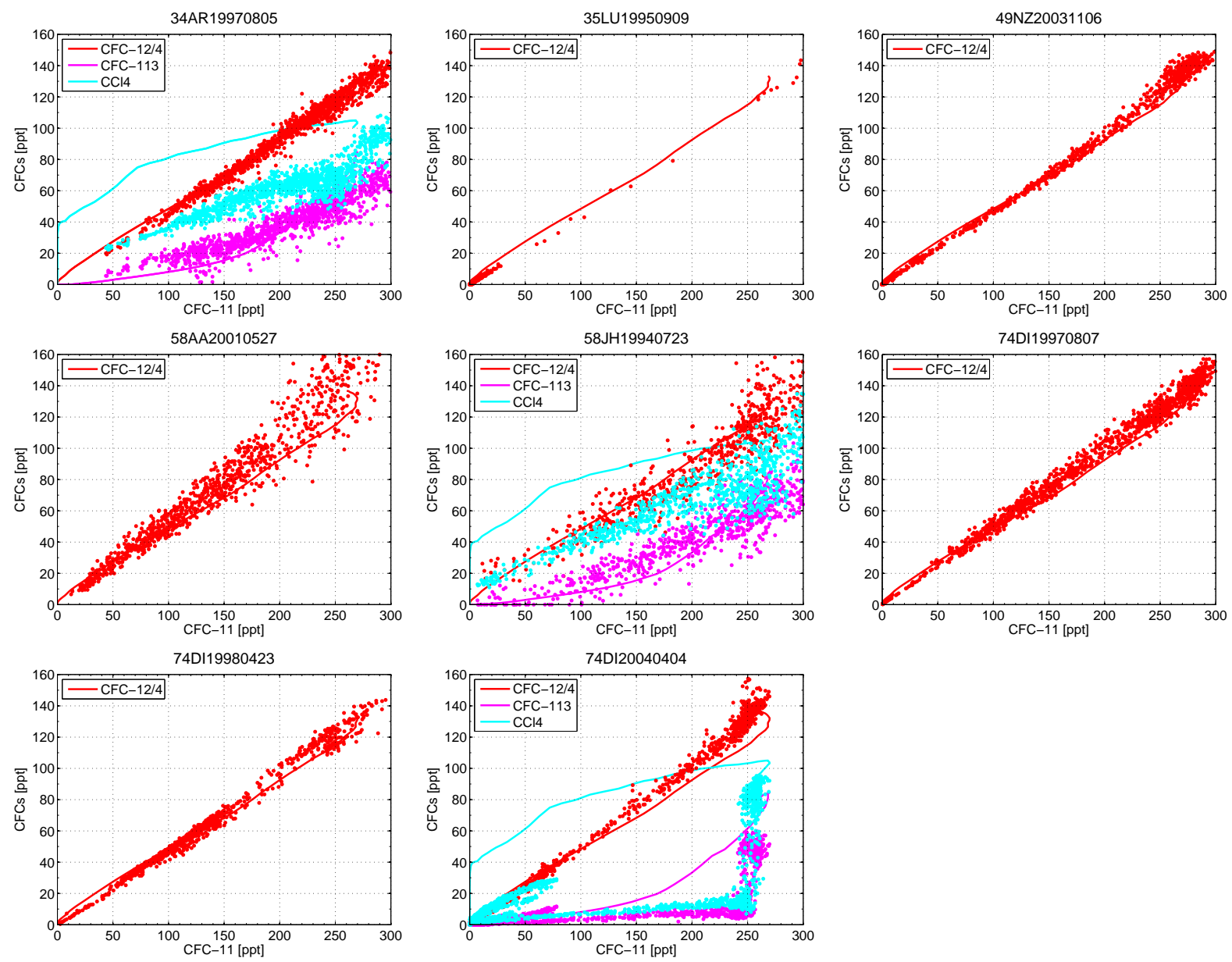

Figure 8. Continued.

\subsection{CFC ratios}

Another method to assess the data quality and possible offsets is the investigation of the CFC ratios throughout the whole water column. In Fig. 8, CFC-12, CFC-113 and $\mathrm{CCl}_{4}$ are plotted against CFC-11. All quantities are converted to atmospheric mixing ratios. The solid lines indicate the atmospheric CFC concentration ratios over time, beginning with zero $\mathrm{CFC}$ concentration and ending with the ratios of the year when the cruise took place. All data in the ocean interior should be located along a mixing line from one point of the atmospheric curve to another point, if the CFC component is stable in seawater. Again, the loss of CFC-113 and $\mathrm{CCl}_{4}$ in warm waters is evident. For $\mathrm{CCl}_{4}$, even at low concentrations, i.e. in old water, a deficit compared with CFC-12 is evident. This can be ascribed to the slow decomposition of $\mathrm{CCl}_{4}$, which occurs in cold deep waters, the rate of this process has been determined to be of the order of $1 \% \mathrm{yr}^{-1}$ for NADW (Huhn et al., 2008). The data in the CFC-11/CFC12 property-property plot, however, span a relatively narrow band in most cases. A larger deviation from the atmospheric curve indicates an offset for at least one of the two CFC components or a poor data quality.

\section{Corrected data sets}

As has been shown in Sect. 3.2, for the Atlantic the results of the crossover analyses do not represent a sufficient basis for a correction of the CFC data. We therefore also consider the surface saturation and the CFC ratios from the ocean interior, as described in Sects. 3.3 and 3.4. Additionally, the results from single crossovers, which are documented on the webpage ("the crossover website", available at http: //cdiac.ornl.gov/oceans/CARINA/Carina_inv.html), are taken into account. For CFC-11 and CFC-12, a correction factor with a multiplicative offset in steps of $5 \%$ is determined, if appropriate. A more accurate determination of the correction factor is not possible by the applied methods. Due to the smaller number of cruises and larger spread of the CFC$113 / \mathrm{CFC}-11$ and $\mathrm{CCl}_{4} / \mathrm{CFC}-11$ ratios both at the surface and in the ocean interior, no correction factor has been applied to CFC-113 and $\mathrm{CCl}_{4}$. In cases where a large spread of the CFC 
ratios occurs, the data quality has been flagged as "poor". CFC-113 and $\mathrm{CCl}_{4}$ data have only been flagged when the data were clearly out of range. Data with a "questionable" or "bad/poor" quality flag (flag 3 or 4) are not included into the CARINA data product. All adjustments and flagged CFC data are listed in Table 2, the justification for these changes of the data and quality flags is given below.

\subsection{CFC-11}

\subsubsection{Cruise \#41, 18HU19940524}

This cruise has a low CFC-11 saturation. The spread of the CFC-11 to CFC-12 ratios is large, but the majority of data points have low CFC-11 concentration. Based on this evidence, an adjustment of 1.05 was applied to the CFC-11 data.

\subsubsection{Cruise \#42, 18HU19941012}

The CFC-11 saturation is more than 5\% smaller than for CFC-12. We would therefore recommend an adjustment of CFC-11 by $1.05-1.1$. However, due to the large scatter in the CFC-11/CFC-12 ratio, both CFC components are flagged as poor and are not included in the data product.

\subsubsection{Cruise \#91, 34AR19970805}

The surface saturation of CFC-11 is relatively high and also larger than for CFC-12. The CFC-11/CFC-12 ratio for most data points is higher than the atmospheric ratio. Based on this evidence, an adjustment of 0.95 was applied to the CFC-11 data.

\subsubsection{Cruise \#95, 35LU19950909}

CFC-11 is clearly oversaturated (about $10 \%$ ), whereas for CFC-12, in comparison, the saturation is smaller. Also the CFC-11/CFC-12 ratio for old waters with low CFC concentrations is above the atmospheric values. Based on this evidence, an adjustment of 0.90 was applied to the CFC-11 data.

\subsubsection{Cruise \#106, 35TH19990712}

CFC-11 in the surface layer is oversaturated by almost $20 \%$. Unfortunately, for this cruise no CFC-12 data exist. Nevertheless, we recommend reducing CFC-11 by $15 \%$. This tendency is also supported from the crossover towards 06BE20001128, which has lower CFC-11 values, although that cruise took place one year later. Based on this evidence, an adjustment of 0.85 was applied to the CFC- 11 data.

\subsubsection{Cruise \#135, 58JH19940723}

The scatter of the CFC ratios in the ocean interior is large for all CFC components. Besides, the surface saturation of CFC-11 is about $110 \%$. Based on this evidence, all CFC components are flagged as poor and not included in the data product.

\subsection{CFC-12 \\ 4.2.1 Cruise \#30, 06MT20030723}

The CFC-12 data of this cruise have been used in Kieke et al. (2007), and there an adjustment of 0.99 has been applied. As this adjustment is below the "threshold" value of 5\% set for the CARINA data set, this correction is neglected.

\subsubsection{Cruise \#37, 18HU19920527}

The CFC-12 saturation is only slightly smaller than for CFC11. At lower CFC concentrations however there seems to be a deficit in CFC-12 despite relatively large scatter in the CFC-11/CFC-12 ratio. Based on this evidence, an adjustment of 1.05 was applied to the CFC-12 data.

\subsubsection{Cruise \#42, 18HU19941012}

Due to the large scatter in the CFC-11/CFC-12 ratio, both CFC components are flagged as poor (see above under CFC11 ), and are not included in the data product.

\subsubsection{Cruise \#43, 18HU19950419}

The scatter in the CFC-11/CFC-12 is large. As for CFC-12 some data points in the DSOW in the western Atlantic are zero, we attribute this scatter mainly to poor CFC-12 data and not to CFC-11. Based on this evidence the CFC-12 data are flagged as poor and not included in the data product.

\subsubsection{Cruise \#84, 33LK19960415}

For this cruise, the CFC-11 surface saturation almost $100 \%$, whereas for CFC-12 the degree of saturation is smaller by about $10 \%$. Almost all CFC-11/CFC-12 ratios are higher than the atmospheric values, and in the crossovers the CFC11 ratio towards the second cruise is larger than the CFC- 12 ratio. Based on this evidence, an adjustment of 1.1 was applied to the CFC-12 data.

\subsubsection{Cruise \#125, 58AA20010527}

The scatter of the CFC-11/CFC-12 ratio increases with increasing $\mathrm{CFC}$ concentration, and the error bar of the regression between CFC-11 and CFC-12 saturation is large. Some near surface $\mathrm{CFC}-12$ data points have been flagged as 'poor' by the AMS group, see Jeansson et al. (2009).

\subsubsection{Cruise \#135, 58JH19940723}

CFC-12 is flagged as poor, as well as the other CFCcomponents, see above under CFC-11. 


\subsection{CFC-113}

\subsubsection{Cruise \#40, 18HU19931105}

The surface saturation of CFC-113 for this cruise is extremely low $(<60 \%)$. Based on this evidence, the CFC-113 data are flagged as poor and not included in the data product.

\subsubsection{Cruise \#41, 18HU19940524}

Again, the surface saturation of CFC-113 is quite low (about $50 \%$ ). Based on this evidence, the CFC-113 data are flagged as poor and not included in the data product.

\subsubsection{Cruise \#44,18HU19970509}

The surface saturation of CFC-113 is small $(<60 \%)$. In the CFC-11-CFC-113 plot the CFC-113 data show a small range of values: they are relatively large at low $\mathrm{CFC}-11$ concentrations and relatively low for high CFC-11 values. Based on this evidence, the CFC-113 data are flagged as poor and not included in the data product.

\subsubsection{Cruise \#135, 58JH19940723}

The CFC-113 are flagged as poor, as well as the other CFCcomponents, see above under CFC- 11 .

\section{$4.4 \mathrm{CCl}_{4}$}

\subsubsection{Cruise \#43, 18HU19950419}

The surface saturation of $\mathrm{CCl}_{4}$ for this cruise is extraordinary large $(>150 \%)$ and the scatter in the $\mathrm{CFC}-11 / \mathrm{CCl}_{4}$ ratio is also large. Based on this evidence, the $\mathrm{CCl}_{4}$ data are flagged as poor and not included in the data product.

\subsubsection{Cruise \#44, 18HU19970509}

The scatter of the CFC-11/CCl $\mathrm{Cl}_{4}$ ratio is large, and some of the $\mathrm{CCl}_{4}$ data seem to be elevated compared with CFC-12. Based on this evidence, the $\mathrm{CCl}_{4}$ data are flagged as poor and not included in the data product.

\subsubsection{Cruise \#135, 58JH19940723}

The $\mathrm{CCl}_{4}$ are flagged as poor, as well as the other CFCcomponents, see above under CFC- 11 .

\section{Concluding remarks}

Applying the adjustment method according to Johnson et al. (2001) to the CFC data of the North Atlantic would result in very large correction factors for CFCs, which is most likely an "overcorrection". We therefore exploited the similar behavior of CFC-11 and CFC-12 to derive corrections factors for these two CFC components based on their surface saturation and their ratios. For $\mathrm{CFC}-113$ and $\mathrm{CCl}_{4}$, however, no correction factors have been determined, only an estimation of the overall data quality for each cruise is given.

As a result of this there are cases where we applied an adjustment, although neither the mean offset nor the LSQ method gives significant mean deviations from 1. In addition, we also rejected corrections of CFC data in cases where the mean offset and/or the LSQ method suggest large corrections. It should be noted that at least the direction of the adjustments is in most cases in agreement with the mean of the crossovers and the inversion results (Fig. 4).

Acknowledgements. This study has been performed as part of the EU project CARBOOCEAN (Project 511176-2). We thank captains, crews, and CFC PIs of the various cruises that contributed to the CARINA-ATL CFC data set. Additional support is provided for R. M. Key (NOAA grant NA08OAR4320752 and NA08OAR4310820) and J. L. Bullister (NOAA Climate Program Office).

Edited by: M. Hoppema

\section{References}

Azetsu-Scott, E. P. Jones, E. P., and Gershey, R. M.: Distribution and ventilation of water masses in the Labrador Sea inferred from CFCs and carbon tetrachloride, Mar. Chem., 94, 55-66, 2005.

Bullister, J. L. and Weiss, R. F.: Determination of $\mathrm{CCl} 3 \mathrm{~F}$ and CCl2F2 in seawater and air, Deep-Sea Res. Pt. I, 35, 839-853, 1988.

Bu, X. and Warner, M. J.: Solubility of chlorofluorocarbon 113 in water and seawater, Deep-Sea Res. Pt. I, 42, 1151-1161, 1995.

Bullister, J. L. and Wisegarver, D. P.: The solubility of carbon tetrachloride in water and seawater, Deep-Sea Res. Pt. I, 45, 12851302, 1998.

Bulsiewicz, K., Rose, H., Klatt, O., Putzka, A., and Roether, W. A capillary-column chromotographic system for efficient chlorofluorocarbon measurement in ocean waters, J. Geophys. Res., 103(C8), 15959-15970, 1998.

Huhn, O., Roether, W., Beining, P., and Rose, H.: Validity limits of carbon tetrachloride as an ocean tracer, Deep-Sea Res. Pt. I, 48, 2025-2049, 2001.

Huhn, O., Roether, W., and Steinfeldt, R.: Age spectra in North Atlantic Deep Water along the South American continental slope, $10^{\circ} \mathrm{N}-30^{\circ} \mathrm{S}$, based on tracer observations, Deep-Sea Res. Pt. I, 55(10), 1252-1276, 2008.

Jeansson, E., Olsson, K. A., Tanhua, T., and Bullister, J. L.: Nordic Seas and Arctic Ocean CFC data in CARINA, Earth Syst. Sci. Data Discuss., 2, 493-536, 2009, http://www.earth-syst-sci-data-discuss.net/2/493/2009/.

Johnson, G., Robbins, P. E., and Hufford, G. E.: Systematic Adjustments of Hydrographic Sections for Internal Consistency, J. Atmos. Oceanic Technol., 18, 1234-244, 2001.

Key, R. M., Tanhua, T., Olsen, A., Hoppema, M., Jutterström, S., Schirnick, C., van Heuven, S., Kozyr, A., Lin, X., Velo, A., Wallace, D. W. R., and Mintrop, L.: The CARINA data synthesis product: introduction and overview, Earth Syst. Sci. Data Discuss., in press, 2009. 
Kieke, D., Rhein, M., Stramma, L., Smethie, W.M., and LeBel, D. A.: Changes in the pool of Labrador Sea Water in the subpolar North Atlantic, Geophys. Res. Lett., 34, L06605, doi:10.1029/2006GL028959, 2007.

Prinn, R. G., Weiss, R. F., Fraser, P. J., et al.: A history of chemically and radioactive important gases in air deduced from ALE/GAGE/AGAGE, J. Geophys. Res., 105, 17751-17792, 2000.

Rhein, M., Fischer, J., Smethie, W. M., Smythe-Wright, D., Weiss, R. F., Mertens, C., Min, D.-H., Fleischmann, U., and Putzka, A.: Labrador Sea Water: Pathways, CFC Inventory, and Formation Rates, J. Phys. Oceanogr., 32, 648-665, 2002.

Roether, W., Klein, B., and Bulsiewicz, K.: Apparent loss of CFC113 in the upper ocean, J. Geophys. Res., 106(C2), 2679-2688, 2001.

Smethie, W. M., Fine, R. A., Putzka, A., and Jones, E. P.: Tracing the flow of North Atlantic Deep Water using chlorofluorocarbons, J. Geophys. Res., 105(C6), 14297-14323, 2000.

Tanhua, T., Steinfeldt, R., Key, R. M., Brown, P., Gruber, N., Wanninkhof, R., Perez, F., Körtzinger, A., Velo, A., Schuster, U., van Heuven, S., Bullister, J. L., Stendardo, I., Hoppema, M., Olsen, A., Kozyr, A., Pierrot, D., Schirnick, C., and Wallace, D. W. R.: Atlantic Ocean CARINA data: overview and salinity adjustments, Earth Syst. Sci. Data Discuss., 2, 241-280, 2009, http://www.earth-syst-sci-data-discuss.net/2/241/2009/.
Tanhua, T., Waugh, D. W., and Wallace, D. W. R.: Use of SF6 to estimate anthropogenic carbon in the upper ocean, J. Geophys. Res., 113, C04037, doi:10.1029/2007JC004416, 2008a.

Tanhua, T., Olsen, A., Hoppema, M., et al.: CARINA Data Synthesis Project. ORNL/CDIAC-157, NDP-091. Carbon Dioxide Information Analysis Center, Oak Ridge National Laboratory, U.S. Department of Energy, Oak Ridge, Tennessee, doi:10.3334/CDIAC/otg.ndp091, 2008b.

Waugh, D. W., Hall, T. M., McNeil, B. I., Key, R., and Matear, R. J.: Anthropogenic $\mathrm{CO}_{2}$ in the oceans estimated using transit time distributions, Tellus, 58B, 376-389, 2006.

Walker, S. J., Weiss, R. F., and Salameh, P. K.: Reconstructed histories of annual mean atmospheric mole fraction for the halocarbons CFC-11, CFC-12 CFC-113 and carbon tetrachloride, J. Geophys. Res., 105, 14285-14296, 2000.

Yashayaev, I.: Hydrographic changes in the Labrador Sea, 1960-2005, Progr. Oceanogr., 73, 242-276, doi:10.1016/j.pocean.2007.04.015, 2007. 